\title{
Cytological features of live limbal tissue donor eyes for autograft or allograft limbal stem cell transplantation
}

\author{
Características citológicas do tecido límbico de doador vivo para transplante autólogo ou alógeno \\ de células-tronco epiteliais corneais
}

Jeison de Nadai Barros ${ }^{1}$, Myrna Serapião dos Santos², Telma Regina Maria Pereira Barreiro², Rubens Belfort JR ${ }^{3}$, José Álvaro Pereira Gomes ${ }^{4}$

\begin{abstract}
Purpose: To evaluate by impression cytology (IC) the corneal surface of live limbal tissue donor eyes for autograft or allograft limbal stem cell transplantation (LSCT). Methods: Twenty limbal donors were enrolled (17 for autograft LSCT and 3 for allograft). Impression cytology was performed before transplantation of superior and inferior limbal grafts and after the third postoperative month.

Results: Impression cytology analysis showed sheets of corneal epithelial cells and goblet cell absence beyond the edge of the keratectomy sites in all patients, suggesting that conjunctival invasion towards the center did not occur in any eye. Partial conjunctivalization within 2 to 3 clock hours, confirmed by the presence of goblet cells, was limited to the keratectomy site in $10 \%$ of the cases.

Conclusion: A clear central corneal surface was demonstrated in all eyes following surgery leading to the conclusion that limbal donation was a safe procedure in this group of patients. A small percentage of eyes can have donor sites re-epithelized with conjunctival cells at the periphery of the cornea.
\end{abstract}

Keywords: Stem cells; Cytological techniques; Limbus corneae; Goblet cells; Epithelial cells; Living donors; Transplantation, autologous

\section{RESUMO}

Objetivo: Avaliar pela citologia de impressão a superfície da córnea de doador vivo para transplante autólogo ou alógeno de células-tronco epiteliais.

Métodos: Vinte pacientes doadores de tecido límbico foram avaliados (17 para transplante autólogo e 3 para alógeno). Os exames citológicos foram realizados em dois momentos: antes da ceratectomia, que removeu tecido límbico dos quadrantes superior e inferior, e após o terceiro mês pós-operatório.

Resultados: Invasão de células da conjuntiva em direção ao centro além da margem da ceratectomia não ocorreu em nenhum olho estudado. Uma pequena área de conjuntivalização parcial, confirmada pela presença de células caliciformes, foi detectada dentro do limite da ceratectomia em $10 \%$ dos casos.

Conclusão: A superfície central da córnea manteve-se transparente demonstrando que a manipulação de tecido límbico em doador vivo foi um procedimento seguro neste grupo de pacientes. Uma pequena porcentagem dos olhos pode ter o local do sítio da ceratectomia re-epitelizado com células da conjuntiva sobre a periferia da córnea.

Descritores: Células-tronco; Técnicas citológicas; Limbo da córnea; Células caliciformes; Células epiteliais; Doadores vivos; Transplante autólogo

\section{INTRODUCTION}

Corneal epithelial cells, as in other epithelia, are continuously produced to compensate for cell loss. This condition is maintained by the corneal epithelial stem cells located in the limbus. The position of the stem cell population at the periphery of the cornea implies a centripetal movement of cells from the periphery toward the central corneal zone ${ }^{(1)}$.

The limbal area also functions as a barrier to the encroachment of corneal epithelium by the conjunctival epithelium. The loss of limbal stem cells leads to conjunctivalization of the cornea which is clinically characterized by superficial neovascularization and chronic inflammation with opacity ${ }^{(2)}$. Primary diseases (aniridia, iris coloboma and neurotrophic keratopathy) or secondary conditions (chemical and thermal injuries, Stevens-Johnson syndrome, ocular cicatricial pemphigoid, contact lens-related epitheliopathy, severe microbial keratitis and multiple surgical procedures at the limbal region) can lead to partial or total limbal stem cell deficiency (LSCD) ${ }^{(3)}$.
In addition to the clinical findings, the demonstration by impression cytology (IC) of goblet cells in the corneal epithelium has been considered as an important diagnostic hallmark of $\operatorname{LSCD}^{(3-7)}$.

The classical treatment for total LSCD is limbal stem cell transplantation. Whenever the contralateral eye is unaffected, limbal conjunctival autograft (CLAU) is considered the best option for ocular surface reconstruction ${ }^{(8)}$. Patients with severe bilateral ocular surface disease can be treated either with limbal allograft from a cadaveric donor (KLAL) or with healthy limbal conjunctival allograft from a living related donor (Ir-CLAL). In the last case, there is the possibility to find a human leukocyte antigen (HLA) matched donor and avoid the use of systemic immunosuppression ${ }^{(9)}$.

Two experimental studies have demonstrated that extensive removal of basal limbal epithelium induced corneal vascularization and conjunctivalization in rabbits ${ }^{(10,11)}$. Nevertheless, there is a general impression by corneal surgeons that limbal donation is a safe procedure with few side effects on the donor eye. As the conditions that cause LSCD are rare and obtaining sufficient numbers of
Submitted for publication: May 26, 2011

Accepted for publication: June 27, 2011

Study carried out at the Department of Ophthalmology - Federal University of São Paulo - UNIFESP. ${ }^{1}$ Certified Ophthalmic Medical Technologist of Visual Science, Responsible for the Impression Cytology, Department of Ophthalmology, Universidade Federal de São Paulo - UNIFESP - São Paulo (SP), Brazil.

2 Physician, Collaborator of External Diseases and Cornea Service, Department of Ophthalmology, Universidade Federal de São Paulo - UNIFESP - São Paulo (SP), Brazil.

${ }^{3}$ Professor, Department of Ophthalmology, Universidade Federal de São Paulo - UNIFESP - São Paulo (SP), Brazil.

${ }^{4}$ Physician, Chief of External Diseases and Cornea Service, Department of Ophthalmology, Universidade Federal de São Paulo - UNIFESP - São Paulo (SP), Brazil.
Funding: This study was supported by Fundação de Amparo à Pesquisa do Estado de São Paulo FAPESP - Projeto Temático 01/07036-3.

Disclosure of potential conflicts of interest: J.N.Barros, None; M.S.dos Santos, None; T.R.M.P.Barreiro, None; Jr.R.Belfort, None; J.A.P.Gomes, None.

Correspondence address: Jeison de Nadai Barros. Al. Gabriel Monteiro da Silva, 1.000 - São Paulo (SP) 01442-000 - Brazil - E-mail: jeisonbarros@hotmail.com 
patients to generate meaningful results remains challenging, very little information is currently available in the literature on the longterm safety of donor eyes following limbal stem cell donation (12). The purpose of this study is to evaluate by IC the corneal surface of live limbal tissue donor eyes for autograft or allograft limbal stem cell transplantation.

\section{METHODS}

A prospective study was conducted between January, 2002 and March, 2008 at the Department of Ophthalmology of the Federal University of São Paulo, Brazil. The protocol was approved by the Investigational Review Board of the institution.

The study included 20 eyes of 20 subjects selected as limbal donors (17 for autograft when diagnosed with unilateral chemical burns and 3 for allograft when diagnosed with bilateral chemical burns). These donor eyes should have not presented previous history of any ocular surgery or ocular surface disease. A detailed ophthalmic examination including biomicroscopy was performed on each donor eye to ensure no preexisting pathology. The medical staff explained to the donors the procedure and its risks and a complete informed consent form was obtained from all patients prior to surgery.

IC samples were obtained from the corneal surface of each patient on three different locations: central region and on the two donor sites (superior and inferior quadrants). In brief, after administration of topical anesthesia with $0.5 \%$ proximetacaine hydrochloride (Anestalcon ${ }^{\circledR} 0.5 \%$, Alcon, São Paulo, Brazil), a strip of acetate cellulose filter paper $(5 \times 7 \mathrm{~mm})$ with a pore size of 0.45 micron (Millipore HAWP304, Bedford, EUA) was placed onto the ocular surface, gently pressed for 5 seconds, and then peeled off. This procedure was repeated for each one of the three locations. All filters were immediately fixed for approximately ten minutes in a solution containing glacial acetic acid, formaldehyde 37\%, and ethyl alcohol in a 1:1:20 volume ratio. All strips were processed for the periodic acid-Schiff (PAS) and Gill's haematoxylin stain ${ }^{(13)}$. From the slide sets, only IC specimens with at least one third of the filter surface filled with epithelial cells were evaluated by optical microscopy. Partial conjunctivalization suggestive of focal LSCD was defined by IC when one or more intact PAS-positive conjunctival goblet cells were found on the corneal surface at the site of the keratectomy ${ }^{(3-6,12)}$.

The surgeries were performed in the 20 donor eyes by 3 experienced corneal surgeons. Donor limbal-conjunctival tissue was harvested from the superior and inferior limbus of the donor's eye. Each graft was 2 to 3 clock hours in length and extended $2 \mathrm{~mm}$ on the conjunctival surface and 0.5-1 $\mathrm{mm}$ on the corneal epithelium. Limbal tissue was dissected to a depth of approximately $100 \mu \mathrm{m}$.

After donating limbal tissue, all patients were regularly evaluated in our service for clinical follow-up. IC was repeated in all donor eyes following the third month of donation.

\section{RESULTS}

From the 20 patients enrolled, ages ranged between 18 and 61 yo with a median of $37 y o$. Fifteen patients were male and five were female. The mean follow-up period was 19.4 months ranging from 4 to 36 months. $75 \%$ of the patients were followed for at least one year. Table 1 shows the interpretation of IC findings. IC analysis showed sheets of corneal epithelial cells and goblet cell absence beyond the edge of the keratectomy sites in all patients suggesting that conjunctival invasion towards the center did not occur in any eye. Partial conjunctivalization within 2 to 3 clock hours, confirmed by goblet cell presence, was limited to the keratectomy site in two eyes (10\%). None of the donor eyes in this study had any complication.

\section{DISCUSSION}

Limbal stem cells integrity ensures normal corneal epithelial resurfacing, preventing conjunctival epithelial ingrowth and its consequences ${ }^{(5)}$. This evidence is essential to understand an important pathophysiologic mechanism presenting in different ocular surface diseases and helps to determine the best strategy for their treatment.

Since the presence of LSCD calls for specific treatment, it is critical to have it diagnosed. LSCD can be confirmed by detection of goblet cells on the surface of the cornea by impression cytology ${ }^{(7)}$. Goblet cells can be easily highlighted by performing routine PAS staining on the specimens ${ }^{(3-4,6)}$. The identification of cytokeratins

Table 1. Cytological feabtures on $\mathbf{2 0}$ eyes following limbal donation

\begin{tabular}{|c|c|c|c|c|c|}
\hline Case & Sex/age & Follow-up months & Limbal graft puprpose & IC results cornealcenter & IC results limbal keratectomy sites \\
\hline 1 & $M / 43$ & 6 & Autograft & Clear & No conjunctivalization \\
\hline 2 & $M / 36$ & 4 & Autograft & Clear & No conjunctivalization \\
\hline 3 & $F / 44$ & 5 & Autograft & Clear & No conjunctivalization \\
\hline 4 & $M / 37$ & 6 & Autograft & Clear & No conjunctivalization \\
\hline 5 & $\mathrm{~F} / 40$ & 12 & Allograft & Clear & No conjunctivalization \\
\hline 6 & $M / 18$ & 10 & Autograft & Clear & No conjunctivalization \\
\hline 7 & $M / 36$ & 15 & Autograft & Clear & No conjunctivalization \\
\hline 8 & $M / 61$ & 12 & Autograft & Clear & No conjunctivalization \\
\hline 9 & $F / 20$ & 19 & Autograft & Clear & Partial conjunctivalization \\
\hline 10 & $F / 49$ & 17 & Autograft & Clear & No conjunctivalization \\
\hline 11 & $M / 26$ & 18 & Autograft & Clear & Partial conjunctivalization \\
\hline 12 & $M / 41$ & 15 & Autograft & Clear & No conjunctivalization \\
\hline 13 & $M / 32$ & 36 & Autograft & Clear & No conjunctivalization \\
\hline 14 & $M / 33$ & 25 & Autograft & Clear & No conjunctivalization \\
\hline 15 & $M / 43$ & 34 & Allograft & Clear & No conjunctivalization \\
\hline 16 & $F / 35$ & 24 & Autograft & Clear & No conjunctivalization \\
\hline 17 & $\mathrm{~F} / 38$ & 36 & Autograft & Clear & No conjunctivalization \\
\hline 18 & $M / 22$ & 31 & Autograft & Clear & No conjunctivalization \\
\hline 19 & $M / 46$ & 27 & Autograft & Clear & No conjunctivalization \\
\hline 20 & $M / 41$ & 36 & Allograft & Clear & No conjunctivalization \\
\hline
\end{tabular}

Legend: $\mathrm{M}=$ male; $\mathrm{F}=$ female; $\mid \mathrm{C}=$ impression cytology 
specific for corneal and conjunctival epithelium has been also proposed for the diagnosis of LSCD, especially if the disease induces an advanced squamous metaplasia with total loss of goblet cells on conjunctiva $a^{(5,7)}$.

Limbal tissue has been generally dissected respecting the epithelial depth and the dissection can include tissue from the peripheral cornea and adjacent conjunctiva ${ }^{(8)}$. Some authors had used only perilimbic conjunctival graft for their ocular surface reconstruction surgery in order to preserve donor limbus and described good results at their period of follow-up ${ }^{(11)}$. Besides, recent reports of a possible stem cell rich area adjacent to the cornea can influence the selection of the donor site for limbal grafts in the future ${ }^{(14,15)}$.

Several variations of limbal autografts and allografts have been described with good reconstruction of the corneal epithelial surface. Although studies demonstrated the survival of donor epithelial stem cells up to 3.5 years after limbal transplantation, the long-term success of limbal allograft transplantation is dependent on the survival of the donor stem cells ${ }^{(16)}$. Thus, a consensus is that autologous limbal grafts (CLAU) have a better prognosis than allogenic grafts $(\mathrm{KLAL})^{(9,17)}$. The most significant advantage of CLAU is the absence of immunologic rejection. However, persistent inflammation of the ocular surface resulting from the original disease, infection, or abnormal eyelids also can cause loss of donor limbal tissue. Although there are no known cases of limbal dysfunction after removal of donor tissue from a healthy human eye, caution is required in cases with chemical burns because the apparently healthy eye may have been involved during the initial trauma. Removal of limbal tissue from a partially stem cell deficient eye may cause irreversible damage ${ }^{(18)}$.

Although studies have demonstrated satisfactory results using limbal tissue from cadaveric donor eyes, systemic immunosuppression of the recipient is necessary to avoid graft rejection after such procedure ${ }^{(19)}$. Several researches prefer using limbal tissue from a living related donor rather than from a cadaver eye. This preference can be explained, because living related tissue provides not only corneal limbal stem cells but also conjunctival epithelial cells, which might be important in cases of severe dry eye. Moreover, it makes it possible to perform HLA matching, which may make systemic immunosuppression unnecessary in cases with totally compatible donors. At the least, it can decrease limbal graft rejection when systemic immunosuppression is decreased in cases with incomplete HLA matching ${ }^{(20)}$

This study demonstrated by IC an intact central corneal surface after limbal donation and partial conjunctivalization within 2 to 3 clock hours limited to the keratectomy site in only $10 \%$ of the cases. Possible explanations for the LSCD located in these two cases can be: surgical manipulation of the limbus inducing a localized loss of stem cells; the mechanical forces elicited by the lids contributing to the damage and a possible focal inflammation causing varying degrees of damage to limbal stem cells $s^{(4)}$.

Similar to the present study, Han and colleagues have reported a clear central corneal surface after limbal donation. Nevertheless, partial conjunctivalization within 2 clock hours limited to the keratectomy site was found in $75 \%$ of their patients (three eyes from a total of four, with a mean follow-up period of 20.8 months ranging from 19 to 24 months) $)^{(12)}$.

There are promising new interventions for LSCD such as ex vivo expansion of limbal stem cells both autologous and allogenic and the use of oral mucosa as a source of epithelial cells. In the first case, a small biopsy of $2 \times 2 \mathrm{~mm}$ is enough to provide the epithelial stem cells necessary to be expanded ex vivo and then transplanted to the diseased eye. In the second case, autologous oral mucosa epithelial cells transplantation can provide a stable corneal surface, but not as transparent as the corneal epithelium . The general feeling is that current literature is still not sufficient to provide evidencebased recommendations on which surgical intervention is most efficacious for each category of $\operatorname{LSCD}^{(17,18)}$.

In summary, this study allowed us to observe a low grade of donor limbal damage following limbal donation. An intact clear central corneal surface was observed following surgery in all patients leading to the conclusion that tissue donation with grafts measuring 2 to 3 clock hours in length from both the superior and the inferior limbus is a safe procedure in humans.

\section{REFERENCES}

1. Tseng SC. Concept and application of limbal stem cells. Eye (Lond). 1989;3 (Pt 2):141-57.

2. Thoft RA. The role of the limbus in ocular surface maintenance and repair. Acta Ophthalmol Suppl. 1989;192:91-4.

3. Puangsricharern V, Tseng SC. Cytologic evidence of corneal diseases with limbal stem cell deficiency. Ophthalmology. 1995;102(10):1476-85.

4. Sridhar MS, Vemuganti GK, Bansal AK, Rao GN. Impression cytology proven corneal stem cell deficiency in patients after surgeries involving the limbus. Cornea. 2001;20(2):145-8

5. Donisi PM, Rama P, Fasolo A, Ponzin D. Analysis of limbal stem cell deficiency by corneal impression cytology. Cornea. 2003:22(6):533-8.

6. Barros JN, Mascaro VL, Gomes JA, Sousa LB, Hofling-Lima AL. Avaliação da presença de células caliciformes na córnea humana. Arq Bras Oftalmol. 2004;67(1):121-5.

7. Sacchetti M, Lambiase A, Cortes M, Sgrulletta R, Bonini S, Merlo D, et al. Clinical and cytological findings in limbal stem cell deficiency. Graefe's Arch Clin Exp Ophthalmol. 2005;243(9):870-6.

8. Kenyon KR, Tseng SC. Limbal autograft transplantation for ocular surface disorders. Ophthalmology. 1989;96(5):709-22.

9. Shimazaki J, Shimmura S, Tsubota K. Donor source affects the outcome of ocular surface reconstruction in chemical or thermal burn of the cornea. Ophthalmology 2004;111(1):38-44.

10. Kruse FE, Chan JJ, Tsai RJ, Tseng SC. Conjunctival transdifferentiation is due to incomplete removal of limbal basal epithelium. Invest Ophthalmol Vis Sci. 1990;31(9):1903-13.

11. Rymer S, Burnier M, Marinho D, Kwitko S, Belfort Jr R, Rohe D. Transplante autólogo de limbo conjuntival e de limbo córneo-conjuntival no tratamento das queimaduras químicas oculares em coelhos. Arq Bras Oftalmol. 2002;65(2):161-70.

12. Han ES, Wee WR, Lee JH, Kim MK. The long-term safety of donor eye for 180 degrees limbal transplantation. Graefes Arch Clin Exp Ophthalmol. 2007;245(5):745-8.

13. Barros JN, Mascaro VL, Gomes JA, Freitas D, Hofling-Lima AL. Citologia de impressão de superfície ocular: técnica de exame e de coloração. Arq Bras Oftalmol. 2001;64(2):127-31.

14. Kaasaki S, Tanioka H, Yamasaki K, Yokoi N, Komuro A, Kinoshita S. Clusters of corneal epithelial cells reside ectopically in human conjunctival epithelium. Invest Ophthalmol Vis Sci. 2006; 47(4):1359-67.

15. Yeung AM, Schlötzer-Schrehardt U, Kulkarni B, Tint NL, Hopkinson A, Dua HS. Limbal epithelial crypt: a model for corneal epithelial maintenance and novel limbal regional variations. Arch Ophthalmol. 2008;126(5):665-9. Comment in: Arch Ophthalmol. 2008; 126(5):725-6.

16. Djalilian AR, Mahesh SP, Koch CA, Nussenblatt RB, Shen D, Zhuang Z, et al. Survival of donor epithelial cells after limbal stem cell transplantation. Invest Ophthalmol Vis Sci. 2005:46(3):803-7.

17. Cauchi PA, Ang GS, Azuara-Blanco A, Burr JM. A systematic literature review of surgical interventions for limbal stem cell deficiency in humans. Am J Ophthalmol. 2008;146(2):251-9. Comment in: Am J Ophthalmol. 2008;146(2):154-5.

18. Shimmura S, Tsubota K. Surgical treatment of limbal stem cell deficiency: are we really transplanting stem cells? Am J Ophthalmol. 2008;146(2):154-5. Comment in: Am J Ophthalmol. 2008;146(2):251-9.

19. Rao SK, Rajagopal R, Sitalakshni G, Padmanabhan P. Limbal allografting from related live donors for corneal surface reconstruction. Ophthalmology. 1999;106(4):822-8. Comment in: Ophthalmology. 2000;107(3):411-2.

20. Gomes JA, Santos MS, Cunha MC, Mascaro VL, Barros JN, Sousa LB. Amniotic membrane transplantation for partial and total limbal stem cell deficiency secondary to chemical burn Ophthalmology. 2003;110(3):466-73. 